Summer 2005

\title{
The Concept of Statutory Law in EU Perspective
}

\author{
Francesico Bilancia \\ University of Chieti-Pescara
}

Follow this and additional works at: https://www.repository.law.indiana.edu/ijgls

Part of the European Law Commons, International Law Commons, and the Legislation Commons

\section{Recommended Citation}

Bilancia, Francesico (2005) "The Concept of Statutory Law in EU Perspective," Indiana Journal of Global Legal Studies: Vol. 12 : Iss. 2 , Article 8.

Available at: https://www.repository.law.indiana.edu/ijgls/vol12/iss2/8

This Symposium is brought to you for free and open access by the Law School Journals at Digital Repository @ Maurer Law. It has been accepted for inclusion in Indiana Journal of Global Legal Studies by an authorized editor of Digital Repository @ Maurer Law. For more information, please contact rvaughan@indiana.edu.

\section{$\Psi$}

JEROME HALL LAW LIBRARY

INDIANA UNIVERSITY

Maurer School of Law
Blooming ton 


\title{
The Concept of Statutory Law in EU Perspective
}

\author{
Francesco Bilancia*
}

\section{The Historical-Political Meaning of Law in the Constitutional Tradition of Continental Europe}

\section{A. From Liberal State to the 1930 s}

The current meaning of the political concept of law is the result of a long and complex historical evolution. The underlying premise is that law does not always follow the development of democratic values. On the contrary, the political datum of the central role of law is constant in the system of the sources of the right of the state, as law is usually the most important source. Thus, our reflection must look for the political roots of the centrality of the law in contemporary legal systems. We must understand why the doctrines of constitutionalism have assigned to the centrality of the law a role and meaning of fundamental instrument for the democratic construction of the state's legal system.

In order to narrow the scope of our analysis, I would start from the liberal state of the nineteenth century. Therefore, I avoid confronting, for example, the study of the concept of law according to the historical-political doctrines of voluntarism (Volontarismo), or the study of the ethical-religious foundations of law-theories that we still find applied today in both totalitarian and theocratic systems.

In different contexts, the law can find its foundation in institutional pluralism, ${ }^{1}$

\footnotetext{
*Doctorate in Public and Constitutional Law, University of Rome "La Sapienza," 1994; Attorney at Law; Professore straordinario di Diritro costituzionale, University of Chieti-Pescara "G. D'Annunzio." This comment was delivered at a symposium on Back to Government? The Pluralistic Deficit in the Decisionmaking Processes and Before the Courts, June 2004, in response to Francesca Bignami, Pluralism, Corporatism and Republicanism in Domestic Public Law: The Implications for a European Right to Civil Society Participation.

1. See, e.g., Magna Carta arts. 12, 39 (1215). The Magna Carta was granted by King John in 1215 and established the seeds of the political foundations of the current notion of the rule of law. Indeed, article 12 established the principle "no taxation without representation," and article 39 based every restriction of the rights of barons on the judgment of their peers according to the law of their land.
} 
in common law, ${ }^{2}$ or in its own representative character. But from the bourgeois state on, the law assumes the essential meaning of the political and legal center of the system of the sources of rights.

As it is well known, the stabilization of the legal doctrine founded on the centrality of the political concept of law arose especially in France and Germany between the middle of the nineteenth century and the 1930s. However, the substantial meaning of this political act, an act enforcing the political choices of government, was still not the one presupposed by the contemporary theories of democracy. This is particularly true in Germany, where the supremacy of the law is due to its attribution to the state, to the sovereign body (the will), and to the supreme institutions.

In the first meaning, the centrality of law is justified inasmuch as it is the child of the sovereignty of the Reich- "the law is the expression of the power of the State" 3 (of the Staatsgewalt) ${ }^{4}$-regardless of how the sovereign functions are differentiated and allocated by the legal system. In this context, the role of the representative body (Parliament) and of the monarch complicate the exercise of the sovereign function. While the former is responsible for defining the content of laws, the latter holds the actual power of adoption through the sanction of the act of command directed at the subjects, in the form of law.

The famous conflict between the Parliament and the Crown, ${ }^{5}$ which occurred in Germany in the second half of the nineteenth century, yielded the cat-

2. The laws of the Parliament themselves-or even better, of the King in Parliament-cannot be entirely compared to the laws of the continental system. Every binding act of the Parliament, in fact, even if it is not prescriptive, is reconverted according to a hermeneutic (airtight) process in the logic of the system of common law (above the mixed English Government). See Giuseppe G. Floridia, Fortuna e crisi del governo misto nella Costituzione inlgese, in Materiali PER UNA storia Della Cultura GiURIDica 305 (2000).

3. Paul Laband, Das Budgetrecht nach den Bestimmungen der Preussischen Verfassungsurkunde unter besonderer Berïcksichtigung der Verfassung des Norddeutschen Bundes, in Zeit fuR Gesetzgebung und Rechtspflefe in Preussen 625 (1870).

4. Staatsgewalt translates to the power of the State, in the sense that it is used in this paragraph.

5. The famous conflict between Parliament and Crown is comprised of two distinct events: the conflict between Landtag and Crown, 1862-1866; and the conflict between Reichstag and Government, 1878. See Carlo Esposito, Legge, in Nuovo Digesto Italiano 720 (Mariano d'Amelio ed., 1938). See also Carlo Roehrssen, Governo, Legge, Politica 135 (1969) and Clementine Forte, Presentazione to Rudolph Gneist \& Georg Jellinek, Legge e bilancio \& Legge e decreto, in Controversi E COSTITUZionali in Base alla Crisi del governo prussiano del marzo 1878, at v (Clemente Forte trans., ed., 1997) ( 1879 ) on the meaning and value of "budget decision." This was the responsibility of Parliament, but it was approved in a different way than the law, which was adopted together by $\mathrm{mmmm}$ 
egories of formal and material law. The comparison between these two concepts will successively illustrate the interpretation of the historical evolution of the relations between law, parliament, and government, concerning the approval of the state budget. The political concept of state will be linked to the formal concept of law because "only the Sovereign or the supreme State power can issue laws." The circumstance in which only the sovereign or the supreme state power can adopt formal legislative acts does not theoretically follow from the concept of law, but from the notion of a state's effective establishment in a given political community. On the contrary, laws in a material sense can be qualified as all the sources authorized by the system to issue legal norms or rules-hence, also the sources of autonomy.

From this context derives, as an immediate consequence, the legal relevance of the form of the act of will that integrates the law. Thus, while in a material sense, legislative right can be considered as a concept equivalent to jus scriptum, in a formal sense, such equivalence will only be true for the written law adopted on the basis of the public consensus (Zustimmung). This leads to a meaningful conclusion: laws, in a formal sense, are also those acts ascribed to the state's will (Willensakte des Staates), for which the consensus of the representative organs (the Parliament) is necessary; yet, they are acts that could not have normative content. $^{\text {? }}$

Paul Laband claims this model has its own underlying political justification in the theory of division of powers. But, according to Laband's theory, the political concept of representation, in reality, does not assume a central role in the categorization of the law, which is instead based on the mere form of the act. In fact, the word "law," in the end, assumes the mere formal meaning of an "act produced resorting to a specific procedure,"

the King and Landtag. From this situation came the theoretical problem of the distinction between "formal law" and "material law." See Rudolph Gneist, Legge e bilancio, in Controversie COSTITUZIONALI IN BASE ALLA CRISI DEL GOVERNo PRUSSIANo DEL MARZo 1878, supra, at 25, 36, 44, 85, 89; see also Georg Jellinek, Legge e decreto, in Controversie costituzionali in BaSe ALLA CRISI del GOVERno Prussiano del marzo 1878, supra, at 230, 237, 254. In opposition to Laband, see the doctrine of Hermann Heller, Il concetto di legge della Costituzione di Weimar, in LA SOVRANITÀ ed ALTRI scritti sulla dottrina del diritto e dello Stato 314, 340 (Pasquale Pasquino trans., 1987) (1928).

6. Paul Laband, Das Staatsrecht des Deutschen Reiches 11 (4th ed. 1991).

7. On the conceptual difference between "law in a formal meaning" and "law in a material meaning," see also Jellinek, supra note 5, at 230,237; Heller, supra note 5, at 314, 340.

8. LABAND, supra note 6 , at $29,32,42$. 
tion (the Parliament) that expresses its own consensus about the content of the state's declarations of will. This value, though, results only because the laws are adopted through the sanction of the Kaiser, regardless of the content of such acts. The two concepts are radically different: one indicative of the form of the declaration of will, and the other indicative of its content.

Further, the concept of law in a formal sense is useful to qualify the subjective holding of the legislative function over a specific material field: competence. The distinction between law in a formal sense and law in a material sense leads to the positivism of the concept of competence. This concept is therefore relevant in the relationship between Bund and Länder, as well as its use with respect to the budget, in the relations between the Parliament (Kaiser and Landtag) and government-though the datum of the substantial identity between legislative power and the state's sovereign authority assumes, in a historical-political context, an authority that cannot be confirmed by the law: "Die Staatsgewalt in abstracto ist durch das Gesetz niemals gebunden."

Therefore, on the one hand, we have competence, which is a product of the state's sovereignty that permits member states to adopt legislative acts only in the capacity based on their autonomy. On the other hand, we have the form that qualifies the acts, which is reserved for the contribution of the political representation of the Parliament. In such a way, the guarantee of dualism is established "between the new institution of representation and the new competences of the sovereign," and between the Parliament and Government, which is typical of the liberal constitutions of the nineteenth century. ${ }^{10} \mathrm{As}$ one can see, representation and a degree of democracy of law are not yet relevant.

One must also consider the role of the Bundesrat in qualifying the value of the representation of member states when deciding the content of the legislative acts adopted through sanctions of the Kaiser. The latter can obtain the application of command acts of the Reich of legislative rank toward the member states and the subjects, although it can never eliminate the material contributions of the same states in defining the contents of the law. For these, the constitutionally competent organ is the Bundersrat, not the Kaiser. The Kaiser, at most, through his own sanction, makes a decision, which is a unitary act of the state's will-an

9. LABAND, supra note 6 , at 74 . The state power in abstracto can never be limited by the law itself.

10. Giuseppe G. Floridia, Regioni, diritto internazionale e diritto comunitario: diritto interno e diritto internazionale: profili storico-comparatistici, at http://www.associazionedeicostituzionalisti.it materiali/convegni/genova020323/floridia.html (last visited Mar. 31, 2005). 
act, which is the synthesis of the will of the individual members of the community and is expressed in the course of the procedure for its assumption within the law of the Reich.

Only later, with Heller, will the law in a material sense become a political act qualified by the principle of the stato di diritto (Rechtsstaat). The law will be an expression of the interest of general will, and will contain supreme law rules issued by the legislative power of the people or by its representation (the Parliament). But as we already observed above, Heller's model is forcefully opposed to the theoretical model presented by Laband. The latter, in fact, is built on the basis of the distinction between the concepts of law in the formal sense and law in the material sense. For Laband, the role of the representation does not concern the relevance of the citizens' interests in determining the contents of the law. Conversely, such a role relates to the formal concept in its capacity as a structural element of the procedure. This results from the influence exerted upon Heller by the revolutionary bourgeoisie from Article 6 of the Declaration of the Rights of Man and of the Citizen of 1789 ("La loi est l'expression de la volonté générale"). ${ }^{11}$

\section{B. Post-Second World War}

One century later, we arrive at the democratic and pluralistic constitution of the post-Second World War era. In the Italian Constitution of 1947, law plays a central role in the system because the law is the most important political act of the Parliament. The constitutional system assigns to the Parliament the central position among the constitutional organs of the state. The Parliament is the political center of the system; it is the most politically representative organ as long as it is directly elected by the people and through a proportionate electoral sys-

11. See Jean-Jacques Rousseau, Il contratto sociale o principi di diritto politico 85, 155 (Gianluigi Barni trans., BUR Milano 1995) (1762); see also the critical positions pointed out during the French Revolution by Maximilien Robespierre, now collected in LA RIVOLUzIONE GIacobina (Umberto Cerroni ed., 1984) and La Rivoluzione giacobina (F. Fabbricini trans., Umberto Cerroni ed., 1992). See id. at 134 (describing the relationship among law, justice, public interest, and "volonté général"). On the "Third State" and its rule in the Revolution and as holder of the "volonté général," and on the meaning of the political concept of "Nation," see EMmanuel Joseph Sieyès, Che cosa è il terzo stato? (Umberto Cerroni trans., 1992); see also Carl Schmitt, Vorbemerkung über den Gegensatz von Parlamentarismus und Demokratie, in Die geistesgeschichtliche Lage des heutigen Parlamentarismus 5, 30, 41 (Duncker \& Hamblot 3d ed. 1961) (1926) (providing a critical position against Parliament's doctrines). 
tem. The Constitution also gives the Parliament a central and dominant role to reduce the political strength of the government. The political forces represented in the Constituent Assembly, which was elected in 1946, radically opposed different ideological clusters and feared an overly strong government in case they lost the political elections.

Naturally, I am trying to simplify issues which are far more complex. The democratic-pluralistic constitutions of the second half of the twentieth century also represent the first important reasons for the crisis of the parliamentary systems. That crisis has several reasons. The first is linked to the advent of mass democracy. It will soon be evident that the parliament will not be as capable of guaranteeing the synthesis of general interests as in the liberal system. The homogeneous democracy of the bourgeoisie class of the nineteenth century was much easier to achieve than the democracy of the contemporary pluralistic system involving all citizens. The political meaning of the law itself will soon change. It is sufficient to confront the meaning of the "reserve of law" (riserva di legge) in the liberal constitutions, and in the democratic ones, beginning with the Constitution of Weimar of 1919. The law loses its role as an instrument for protecting bourgeoisie property against the risk of arbitrary expropriations. The law will no longer be the instrument by which the parliament defends the class of proprietors-the only class represented by the law-against the aggressions toward their property. Article 153 of the Constitution of Weimar calls upon the law to discipline the very content of the property right. The property right must guarantee the interest of the public and other subjects together with the interest of the proprietor of the good. The legislator no longer protects the notion of property rights, the sole interests of the proprietor, but rather has to construct the synthesis of several interests in a single norm. In this way, the law changes its own role and its own structure. It is no longer just a condition of legitimacy for the expropriation of the inviolable right of property, no longer the reserve of competence in favor of the bourgeoisie, but is rather an instrument for the discipline of the content of the right and its limits. ${ }^{2}$ The political consequence of this historical datum thus will be the transformation of the law from an instrument for the protection of the interests of the bourgeoisie into an instrument for the mediation of the social conflict.

12. The principle in the Weimar Constitution, then translated in the Grundgesetz, settles that "Eigentum verpflichtet. Sein Gebrauch soll zugleich Dienst sein für Gemeine Beste." 
But the crisis of the systems also depends on other, more strictly juridical, reasons. There is the birth of rigid constitutions-constitutions that the law itself cannot modify. A "superior law"13 (law that must be respected) is associated with the control of constitutionality over contents of the law, to guarantee the superiority of the constitution. In this way, the law loses its political primacy in the system although it remains the normative act, which is politically central for the development of the system. The constitution will place alongside law other equally important normative acts: governmental acts, acts of autonomous bodies, and acts of reserved competence. However, the strongest meaning of the law as a political act survives: the capability to give democracy a visibly practical sense. The idea of law held by contemporary jurists, in fact, represents both the essence and value of democracy. ${ }^{14}$ It represents all interests involved in a decisional process: the discussion among conflicting interests, their synthesis, and the building of a new object-the general interest. The etymology of "parliament" suggests the values of dialectics, debate, and proper procedure. In short, it is seen as an instrument of compromise. In the debate between parties, most diverse interests-through mediation, agreement, and compromise, achieved by respecting the parliamentary procedures-merge together and transform into something different: namely, the general interest. This is the deep nexus between a parliamentary system and democracy. No other rulemaking process can guarantee such a strong participation of different interests that results in the construction of a rule that will govern them all.

The law, in the system of the "legislative parliamentary state," 15 used to be the moving center of the political system because the parliament, or the bourgeoisie class, was the supreme body of the system. Conversely, the law of the contemporary legal culture is assumed to be the voice of political representation, as the expression of the general will. Perhaps such an idea can be considered an illusion, but it represents the political principle upon which the modern concept of democracy is founded.

This is the theoretical datum that justifies my proposition: every system and every foundation of legitimation of the legislative power that we have considered in a given historical moment depends on a political principle. Such a politi-

13. See generally Marbury v. Madison, 5 U.S. (1 Cranch) 137 (1804).

14. See generally Hans Kelsen, Vom Wesen und Wert der Demokratie (1929).

15. Traditionally we refer to the French Constitution of 1875. Les LoIs Constitutionnelles de LA IIIÈMe République (1875) [Constitutional Laws of the Third Republic]. 
cal principle that governs the legal system creates the foundation of the system: the will of the sovereign in the absolute monarchy; the will of God in the theocratic state; the will of the bourgeois parliament in the liberal state; and the interests of the people in the contemporary democracy. However, there is yet another main problem today: how do the interests of the people translate into the contents of the juridical norms? Is the law of the parliament still the most effective instrument? I believe so. Indeed, I believe that it is the only instrument, as long as the parliament is truly representative. Here, I put forward a concrete example: the current Italian majority system does not guarantee Parliament the exercise of its representative function. The Italian Parliament does not work within legislative procedures to find an agreement to absorb the social conflict and political tensions among the people. It is an instrument of the majority, which creates strong marginalization. The most direct consequence of this datum is the mutual delegitimation of the conflicting parties, but this is yet another story.

\section{The Civil Society's Participation in Decisionmaking Procedures: A Critical Point of View}

I do not like the idea that the direct participation of the interests involved in the decisionmaking process represents a different form of democracy. I do not believe that individual European citizens, companies, private associations, unions, and churches-in short, the civil society of the White Paper on European Governance ${ }^{16}$ — can really participate in the decisionmaking processes of the European Union (EU), effectively substituting a representative parliament. The idea is not new. For instance, Niklas Luhmann, in his famous 1969 essay entitled Legitimation durch Verfahren, had already proposed a critical analysis of such a model. This book is important for its content and not just its title. I say this because often the title of this volume has been used as a synthesis of its contents, at least in the Italian literature, as if the book were meant to demonstrate that the participation in the decisionmaking process is sufficient to politically legitimize a decision. But this is not what Luhmann recounts in his book. To the contrary, Luhmann intended to construct the role of the participation of citizens in decisionmaking processes as a category of justice. The idea presents the struggle of individual rights against the

16. Commission of the European Communities, White Paper on European Governance, $\operatorname{COM}(2001) 428$ final. 
establishment, as opposed to the rights as instruments to legitimize the establishment. The participation must allow equal chances for all the interests compromised by a given decision (substantial justice) and search for the objective truth through the rules (due process of law). Franco Ledda, an important Italian scholar of administrative law, described the participation in the decisionmaking process in opposite terms to the ones used in the White Paper, such as "[i]n praise of dissent" and "resistance of the interests," and not the manifestation of the consensus.

This is the background issue, the pivotal point, and the main objection to the proposed model. In this context, the rights of participation are instruments of warranty against the illegitimate forms of exercising power. The model should provide: (a) rights of political participation that guarantee the democratic nature of the system; and (b) rights of defense against aggression toward one's goods and substantial interests by the use of democratic power. Constitutionalism has accustomed us to this way. The rule of law defends the rights of individuals even against democratic decisions, but the model of governance pays attention to only one of the two elements; indeed, it conflates one within the other.

The participation of various interests in the political process will never be equal for all. Not all of the interests involved in the decisionmaking process have the same strength, the same capability, or the same information. The conclusion is obvious: the participatory rights are privileges for the few, not rights for all. The absence of equality in the rights of political participation is incompatible with the idea of contemporary democracy. European citizens have become consumers. Is the meaning of the two words the same?

In a different context, we should pay attention to every form of sectorial agreement that could facilitate compromise each time the interests involved in a decisionmaking process are complex and in contention with each other. I am thinking now of a new form of negotiation among labor unions (syndicates), firms, associations, and the government, like we had in Italian politics during the 1990s. Agreements have been implemented to plan some important economic and financial policies by the public institutions, by involving private and social actors in public decisionmaking, and this could enforce common consent on public policies, even when painful for the people. This way of shaping policies' content is called in Italy "concertazione," 17 and, in the European context,

17. On the recent Italian experience, see Giorgio Fontana, Crisi della legge e negoziazione legislativa nella transizione istituzionale italiana, in TRAsFormazIONI DELLA FUNZIONE LEGISLATIVA, II, CRISI della legge e sistema delle fonti 117 (Franco Modugno ed., 2000). 
should be used to affect communitarian directives in social fields (Amsterdam Treaty). This is a kind of alternative participation in decisionmaking processes that I approve as a real form of consent of private interests on public choices because of both its highly representative capability of the subjects involved, and the importance, in the democratic sense, of equality in rights to participation.

\section{An Example: The Works of the Convention on the Future of The EU}

\section{A. The New "European Law Acts"}

The Draft Treaty Establishing a Constitution for Europe for the first time proposes to modify the name of the EU normative acts. The regulation will be called European law; the directive becomes European framework-law. The name "European law" clarifies what the role of this normative act should be, but is its nature comparable to the nature of the law of the state? The EU system, in fact, is not founded on the principle of division of powers. There is no theory of sources in EU law, and no attention is given to the formal and substantial characteristics of legislative acts. We do not have appropriate juridical categories (terms) to understand the following questions: Why should legal acts have a specific form (typical formal signs) and a specific content (general, abstract, normative)? Why should they be distinguished by types? Why should we look at the subject (the organ) that adopts the normative act to classify this act? There are no answers to these theoretical questions in the European system.

Furthermore, European law does not recognize autonomous legitimation for political action as such. In the national systems, each government is free to decide its own policy within the framework of constitutional rules. Is the case the same in Europe? The problem of which European institutions correspond to state government is beyond the scope of this paper. It is a complex question to which I tried to provide the answer in another paper. ${ }^{18} \mathrm{I}$ am content with remarking that the normative structure of EU treaties produces the neutralization

18. See Francesco Bilancia, Presentation at the Conference on La costituzione materiale: percorsi culturali e attualità di un'ideaz, Brevi note su costituzione materiale, legalità ed Unione europea, Intervento (Mar. 16-18, 2001), reprinted in La costituzione materiale: Percorsi culturali e attualità di u'idea, in Quaderni della Rassegna parlamentare 425 (A. Catelani \& S. Labriola eds., 2001); see also Francesco Bilancia, I diritti fondamentali come conquiste sovrastatali di civiltà: Il diritto di PROPRIETÀ NELLA CEDU 18 (2002). 
of every political motion (action). ${ }^{19}$ The institutional aims of the European system, in fact, are all described in the provision concerning the market economy, competition, and EU policies. Out of the competences established by the norms, there is no room for political autonomy. It is the states that, in building the systems of the treaties, have already set all the targets of the EU. They have composed such targets in detail in a set of enumerated competences. They have protected such targets by entrusting the Commission with legislative initiative and vigilance over the application of EU laws.

Such a normative technique is entirely resumed by the project of the constitutional treaty. The competences of the $\mathrm{EU}^{20}$ are all defined as procedures to be applied according to the dispositions contained in Title 3 of the Treaty. Moreover, the European policy is subject to rigorous judicial control by the Court of Justice in order to guarantee respect for the legal parameters in which the policy is bridled; according to the importance of this judicial review in the European legal system, Massimo Severo Giannini, one of the most important Italian jurists of the twentieth century, had already proposed to qualify the EU law as a system of administrative law (in the sense that it is "nonconstitutional"). ${ }^{21}$

However, there is a paradox in that system: the Court of Justice is the only authority endowed with political initiative, and it is strongly determined to use all its power, well beyond the content of the treaties and perhaps against the states' wills. The Court of Justice is the only institution that politically stimulates the system, ${ }^{22}$ apart from the states, within the European Council. The rest is all planned, in detail, by the norms, procedures, competences, and agencies of control, and guarantees respect for EU law, in the hands of the Commission and the Court itself.

But which acts, decisions, or decisionmaking procedures should be rendered more democratic? Making a decision and making the procedure more transparent are both noble goals and important commitments, and the Commis-

19. See Gianni Ferrara, I diritti politici nell'ordinamento europeo, in A.I.C., LA Costıtuzione EUROPEA 473 (2000).

20. See Treaty Establishing a Constitution for Europe, signed Oct. 29, 2004, art. I-12, 2004 O.J. (C 310).

21. See Massimo Severo Giannini, Profili di un diritto amministrativo delle Comunità europee, Address at a 1967 conference in Rome, reprinted in Riv. Trim. Dir. Pubbr 982 (2003).

22. See Marco Dani, Dall'inquietudine all'integrazione: riflessioni su mercato e socialità nello spazio costituzionale europeo, in IL processo di costituzionalizzazione dell'Unione europea: Saggi Su Valori E pRescrittività dell'integrazione costituzionale sovranazionale 315 (R. Toniatti \& F. Palermo eds., 2004). 
sion seems to be aware of this. But is it really possible that, apart from transparency, the effective participation of the involved interests can be guaranteed? Are we sure that the participation of all the involved interests-for example, the interests of both the large company, on the one hand, and the individual citizen/ consumer, on the other - could be effective without selection and in a regime of substantial equality? I remind the audience that, at least in Italy, the consumers' associations are neither open nor representative; they perform a mere lobbying activity in the tutelage of specific interests.

We should also consider that the EU system is basically oriented along the case law of the Court of Justice, which is implemented in the states' legal systems as compulsory European Law. This order is constitutionally implemented more by jurisprudence ${ }^{23}$ than by the legal acts of Parliament and Council. That is why I do not understand what the text of the Charter of Fundamental Rights of the Union will mean for the advancement of the law considering that the protection of fundamental rights should be provided for by law. ${ }^{24}$ There will not be a European law until the new treaty is in force. The only European law that has regulated this subject until now is the Court of Justice's case law, which represents the foundations of the Charter itself. But this case law is not able to create a new European common law, because the European Council law is not "common" at all. It is not based on equality among citizens (there are no peers). Instead, the law proceeds from a specific political program, ${ }^{25}$ which is well-known and gives rise to a compound system of interests, in which individuals and big corporations are considered equal. When Article 6 of the EU Treaty says, "The Union is founded on the principles of democracy and the rule of law and principles which are common to the Member States," it certainly refers to the classical, common concept of democracy, founded on parliamentary legal procedures, ${ }^{26}$ open to all the interests there represented. Thus, the democratic foundations of the Union are a synthesis of the traditional cultural concepts of citizens' participation, subject to the law and

23. See Roberto Toniatti, Il principio di rule of law e la formazione giurisprudenziale del diritto costituzionale dell'Unione europea, in Costituzione italiana e diritro comunitario: Principi e TRADIZIONI COSTITUZIONALI COMUNI: LA FORMAZIONE GIURISPRUDENZIALE DEL DIRITTO COSTITUZIONaLe europeo 503 (Silvio Gambino ed., 2002).

24. Charter of Fundamental Rights of the European Union, art. 52, \1, 2000 O.J. (C 364) 21 ("Any limitation on the exercise of the rights and freedoms recognised by this Charter must be provided for by law.").

25. See Dani, supra note 22, at 305.

26. See M.P. Iadicicco, Fonti comunitarie e riserva di legge, in Diritto pubblico interno e comuNITArio (2004) (Ph.D. dissertation, Seconda Università degli Studi di Napoli). 
decisionmaking procedures, with all their conflicting interests represented in those procedures. ${ }^{27}$ Equality of chances is the topic of the question. And this equality could not be guaranteed by the principle of "participatory democracy" set forth in Article I-46 of the Treaty Establishing a Constitution for Europe. ${ }^{28}$

\section{B. The Complex Structure of European Legislative Institutions}

In general, scholars propose a parallel analysis between the legislative procedure of the EU, which involves the Commission, the Council, and the European Parliament, and one of the individual Member States. Such a comparison, even if useful, is not simple. In the EU there is no trace of the division of power between legislative institutions and governmental institutions. The analysis should be conducted by separating the interests of the community (defined by the treaties but decided by the states), the interests of the government, the interests of the citizens, and the interests of the firms. But I cannot make such a division in order to allocate them to different institutions. In other words, I believe that it is not easy to imagine for the EU the same institutional balance that has characterized the mixed English government for several centuries. I am referring to the historical balance among the interests of different social classes in the trilateral relations between the English Crown, Lords, and Commons. Further, an important point for me is that the normative acts of the EU are not like the laws of the states. They do not represent the fundamental political choices of the system. Such choices are already written in the treaties. The European laws are mere acts of execution of such choices-my issue stems from this very fact. If we think about how the mixed English government was created, how the parliamentary regime came about in that system ${ }^{29}$ (since the first traces written in the Magna Carta of 1215), and how some institutions have evolved (such as the Privy Council, first, and the Cabinet at a later stage), we can learn an important lesson in order to evaluate the role played by the panels as political institutions. The power of the panel was established in opposition to the monocratic power of the

27. See the very interesting reflections of M. Dani \& F. Palermo, Della governance e di altri demoni (un dialogo), in QuAderni costituzionali 785 (2003).

28. So I finally agree with the conclusions of Francesca Bignami, Three Generations of Participation Rights in European Administrative Proceedings (Jean Monnet Ctr for Int'l \& Reg'l Econ. L. \& Justice, N.Y.U. Sch. of L., Jean Monnet Working Papers No. 11/03, 2003), available at http://www.jeanmonnetprogram.org/papers/03/031101.html (last visited Apr. 1, 2005).

29. Here I refer literally to the teachings of Gianni Ferrara. 
King. English constitutionalism teaches that the diffusion of power is obtained through the political panel. Panel means pluralism in the selection process, as well as the synthesis of the interests to be represented in decisions. In England, in reference to such interests, the barons will be considered first, then the interests of the Commons, and finally the interests of the populace. Conversely, what is the representative role played by the Council of Ministers--the highest political authority of the EU? Is it also a panel created to diffuse the power into pluralism? No, it is not. Rather, it represents the EU government, its own policies, and the various interests separated by nationality.

Indeed, we face the opposite case: the Council of Ministers is a panel created to concentrate power ${ }^{30}$ and to separate the political responsibility of each of its members from the control of the citizens of each Member State. It is a panel that creates this effect; through mutual legitimation, it breaks the link between these members and their responsibilities toward their citizens. Each decision made in Europe is then imposed on the Member States. The governments decide together and then implement these decisions independently. In so doing, their actions are immune from any consequences. The Ministers legitimize their actions by attributing them to their constituents, saying essentially, "Europe asks this from us!"

In his capacity as the Vice President of the Convention for the Future of the $\mathrm{EU}$, the organ entrusted ${ }^{31}$ with writing the first draft of the new European constitutional treaty, Giuliano Amato put forth an interesting proposal to break the dependency of the EU Council on the national governments. His proposal is to transform the "Legislative and General Affairs Council" 32 into a permanent organ, composed no longer of the same ministers of the state governments, but by ministers chosen and appointed ad hoc. They would still be state ministers, but they would stay permanently in Europe. In this case, we would have a true European Parliament-a legislative parliament, typical of federal states. The

30. See again the theoretical position and the scientific doctrine of Gianni Ferrara, La sovranità statale tra esercizio congiunto e delega permanente, in Ripensare lo Stato: atti del Convegno di studi, Napoli, 22-23 marzo 2002, at 657 (Silvano Labriola ed., 2003).

31. Council of the European Union, Presidency Conclusions: European Council Meeting in Laeken 14 and 15 December 2001, Laeken Declaration on the Future of the European Union, SN 300/1/01 REV 1, available at http://ue.eu.int/ueDocs/cms_Data/docs/pressdata/en/ec/68827.pdf (last visited Mar. 10, 2005).

32. The European Convention, Secretariat, Draft Treaty Establishing a Constitution for Europe, art. 23, If l, CONV 850/03, available at http:/european-convention.eu.int/docs/Treaty/ cv00850.en03.pdf (last visited Mar. 10, 2005). 
Parliament would have two chambers. One chamber would be appointed by the citizens, and the other would represent the governments of the Member States. This second chamber would work for the general interest more efficiently, being less dependent upon the governments. Indeed, such a chamber would be slightly more distant from the interests of the individual governments, and thus slightly more motivated to pursue a superior general interest, which would be perhaps closer to the European Parliament. However, the state governments did not accept this solution; thus, nothing will change in the EU institutional setting.

What remains is the current European Parliament and its battles before the European Court of Justice in order to maintain, inasmuch as it is possible, the procedure of co-decision. Once again, we need to wait for the practical actions of the EU institutions to determine which interests will prevail in the European decisionmaking procedures. Yet, the deficit of representation in the European institutions will remain the same. In theory, every representative organ, to be truly representative, must reproduce the same structure as the represented body. ${ }^{33}$ Therefore, the parliament of a complex society should represent the plural society as a whole. In other words, the parliament should reproduce the organic structure of the source of its own legitimacy. One such example is civil society. In order to involve a civil society in the decisionmaking process, the representatives must participate in the workings of the EU Convention. They have been heard in a single hearing, together with the representatives of the regional bodies, the advisory bodies and all the other subjects who are marginally involved in the process of the project's development. Although this appears to be democratic participation at work, we must keep in mind that the Convention put forth a draft constitution without having received any popular mandate and without voting even once. The draft has been adopted by a consensus. I also think we need more participation, more information, more equality, more intellectual honesty, and more democracy. But how can those be achieved, if not through an actual and effective representative regime?

33. Ferrara, supra note 30. 


\section{NWSA}

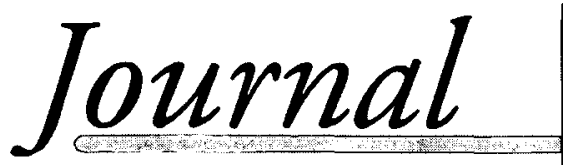

...the most relevant, interdisciplinary, multicultural feminist scholarship of the day...
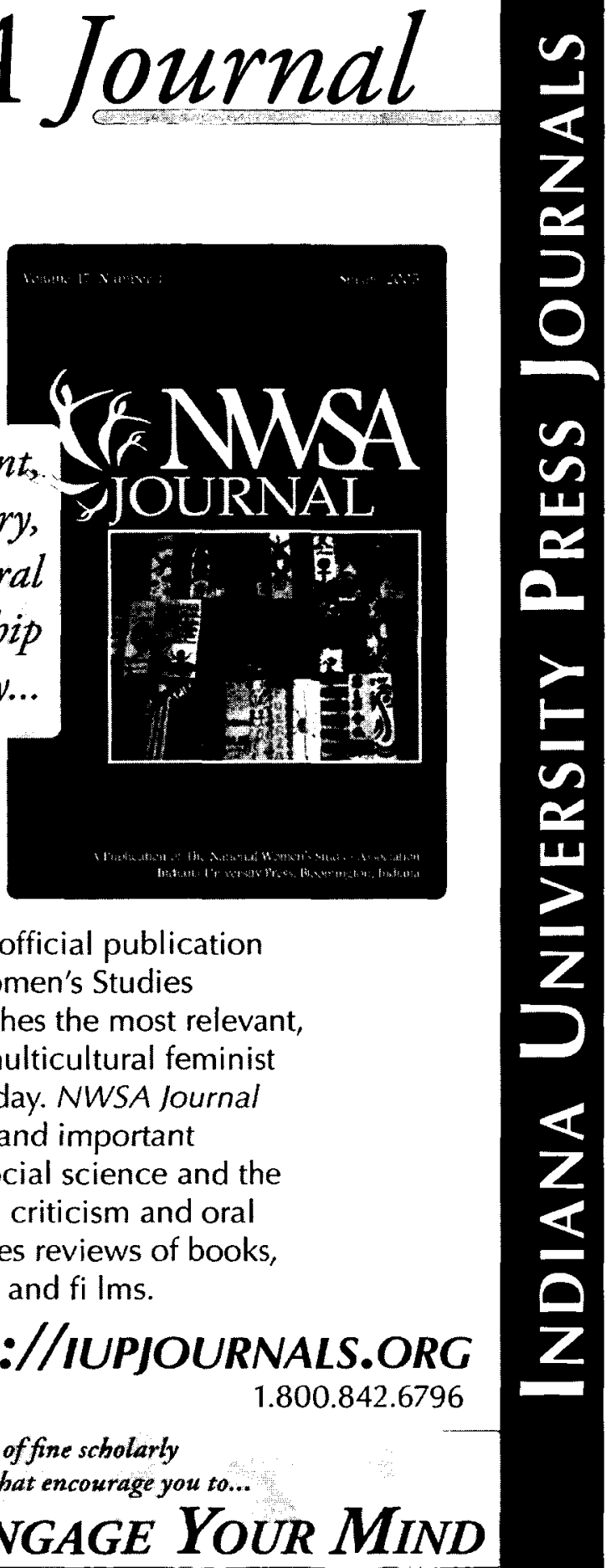

NWSA Journal, an official publication of the National Women's Studies Association, publishes the most relevant, interdisciplinary, multicultural feminist scholarship of the day. NWSA Journal features intriguing and important essays, balances social science and the humanities, textual criticism and oral history, and provides reviews of books, teaching materials, and fi Ims.

\section{HTTP://IUPJOURNALS.ORG} 1.800 .842 .6796

INDIANA University Press:

Publisher of fine scholarly journals that encourage you to... jouthals ENGAGE YOUR MIND 